\title{
Cultural and human dynamics in southern Arabia at the end of the Middle Paleolithic
}

\author{
Anne Delagnes ${ }^{\mathrm{a}, \mathrm{b}, *}$, Rémy Crassard $^{\mathrm{c}}$, Pascal Bertran ${ }^{\mathrm{a}, \mathrm{d}}$, Luca Sitzia ${ }^{\mathrm{a}}$ \\ ${ }^{a}$ CNRS - Université Bordeaux 1, PACEA UMR 5199, Avenue des Facultés, 33405 Talence, France \\ ${ }^{\mathrm{b}}$ Institute of Human Evolution, University of the Witwatersrand, Private Bag 3, Wits 2050, South Africa \\ ${ }^{c}$ CNRS - Université Lyon 2, Archéorient UMR 5133, Maison de l'Orient et de la Méditerranée, 7 rue Raulin, 69007 Lyon, France \\ ${ }^{\mathrm{d}}$ INRAP, 156 Avenue Jean Jaurès, 33600 Pessac, France
}

\section{A R T I C L E I N F O}

\section{Article history:}

Available online 9 January 2013

\begin{abstract}
A B S T R A C T
The Arabian Peninsula has long been considered as a region devoid of long-term human settlement until the Holocene period, as a result of drastic climatic changes throughout the Pleistocene. It might be expected that the area was deserted during hyper-arid and arid periods, and populated by new migrant groups during humid events, according to a "push and pull" phenomenon. Although this scenario may be perfectly valid for a large part of the Peninsula, a set of recent data points to the persistence of populations in several regions, which may have served as refugia for human groups who developed their own technological traditions. Such a scenario is suggested by:
\end{abstract}

(1) The succession of dense human occupations under arid conditions between ca. 60 and $50 \mathrm{ka}$, in the Wadi Surdud basin, a small sedimentary basin in the foothills of the Yemeni Western Highlands. This archaeological site complex encompasses several successive human settlements characterized by a Middle Paleolithic tradition which significantly differs from the Middle Paleolithic and Middle Stone Age contemporaneous traditions from neighboring regions;

(2) The regional diversity of the Middle Paleolithic throughout the Saharo-Arabian arid belt during MIS 3 , expressed by an array of local techno-typological facies that likely relate to distant and disconnected source regions where populations contracted when climate worsened.

Together with a set of high-resolution archaeological contexts recently discovered in the Arabian Peninsula and dated to MIS 5, these data suggest that the major human expansion waves which occurred in the region during the Upper Pleistocene are correlated with the wet phases of MIS 5, while populations probably contracted into a few refugia areas at the beginning of MIS 3 .

(c) 2013 Elsevier Ltd and INQUA. All rights reserved.

\section{Introduction}

Over the last two decades, the Arabian Peninsula has played a major role in the issues relating to the expansions of populations of Anatomically Modern Human (AMH) out of Africa. Combining the genetic record (Quintana-Murci et al., 1999; Forster and Matsumura, 2005; Macaulay et al., 2005) with a demographic

\footnotetext{
* Corresponding author. CNRS - Université Bordeaux 1, PACEA UMR 5199, Avenue des Facultés, 33405 Talence, France.

E-mail address: a.delagnes@pacea.u-bordeaux1.fr (A. Delagnes).
}

and climate-based modeling approach, the "Out of Africa 3" scenario speculates that the expansion of East African AMH occurred ca. 60 ka following a southern Arabian route along either the Indian Ocean or the Red Sea shores during one or multiple wet phases (Clark, 1989; Lahr and Foley, 1994, 1998; Stringer, 2000; Rose, 2007a). Conversely, Arabia would have been deserted by humans during the arid and hyper-arid or tabula rasa events (Rose, 2007b) throughout the Pleistocene. Testing these hypotheses, and in particular the timing, environmental conditions and trajectories of the AMH expansions out of Africa through the archaeological record is a challenging task for a number of reasons which first relate to the specific environmental characteristics of the region: 
(1) Some three-quarters of the more than 3 million $\mathrm{km}^{2}$ total area of the Arabian Peninsula are covered by deserts, where the opportunities for recovering Pleistocene stratified archaeological contexts are limited to isolated paleolakes (Petraglia et al., 2011, 2012; Rosenberg et al., 2011, 2012).

(2) A large portion of the Arabian Pleistocene shorelines and its potential archaeological record are now submerged, in particular for the time periods corresponding to the phases of marine regression, when the distance between the sides of the Red Sea was the most favorable for sea crossing (Bailey et al., 2007; Bailey, 2009; Lambeck et al., 2011). The Arabian Peninsula has a narrow continental shelf exposed during the Pleistocene marine low stands with two major exceptions, the drying up of the Persian Gulf and the considerable narrowing of the Bab al Mandab strait with substantial coastal flats exposed between Yemen and Saudi Arabia. Furthermore, there are some sunken landscapes but at a much smaller scale along the Omani coast of the Indian Ocean.

(3) Pleistocene environmental proxies are lacking, given the scarcity of accessible sedimentary deposits and the very poor preservation of organic material.

As a consequence, the archaeological data available originate mainly from non-stratified and undated open air localities where Acheulean, Middle Paleolithic and Neolithic artifacts are often mixed on sites' surfaces (Caton-Thompson, 1938, 1953; Van Beek et al., 1963; Inizan and Ortlieb, 1987; Whalen and Pease, 1991; Amirkhanov, 1994; Petraglia, 2003; Petraglia and Alsharekh, 2003; Crassard, 2008; Scott-Jackson et al., 2008), and not a single Pleistocene human fossil has been recovered in the whole Arabian Peninsula. While these sites perhaps have a low potential per se for discussing expansion models in and across Arabia, they provide valuable information when compared with stratified contexts at a local scale. The increased interest in the Arabian Pleistocene archaeological record over the last decade (see Groucutt and Petraglia, 2012) has resulted in the recovery of several stratified archaeological complexes in Oman (Rose et al., 2011), in the United Arab Emirates (Armitage et al., 2011), in Saudi Arabia (Petraglia et al., 2011, 2012) and in Yemen (Delagnes et al., 2012). Although the mesh size is still very coarse given the overall area of the Arabian Peninsula (Fig. 1), these occurrences point to more complex and diverse settlement patterns than suggested so far by the "Out of Africa 3" or Recent African Origin model (Stringer and Andrews, 1988). Furthermore, several occurrences suggest the development of local Middle Paleolithic traditions during phases of aridification. They result from long-term or recurrent human settlements in distinct desert margin areas that have provided sustainable biotic resources. This paper discusses the role played by these desert margin areas for the populations that occupied the Arabian Peninsula during Marine Isotope Stage (MIS) 3, based on the recent outcomes of the Wadi Surdud archaeological complex (Delagnes et al., 2012; Sitzia et al., 2012), in the context of the most recent discoveries.

\section{Wadi Surdud regional setting}

The Wadi Surdud site complex, located in the al-Mahwit/ Tihama region of Yemen (Fig. 1), forms the only known stratified site complex in the western part of Arabia that directly faces the African continent. The Wadi Surdud basin is filled with a $32 \mathrm{~m}$ thick alluvial terraced sequence. The archaeological sites are distributed along two small desiccated tributaries of Wadi Surdud: Shi'bat Dihya and Al-Sharj, at elevations ranging from $360 \mathrm{~m}$ to

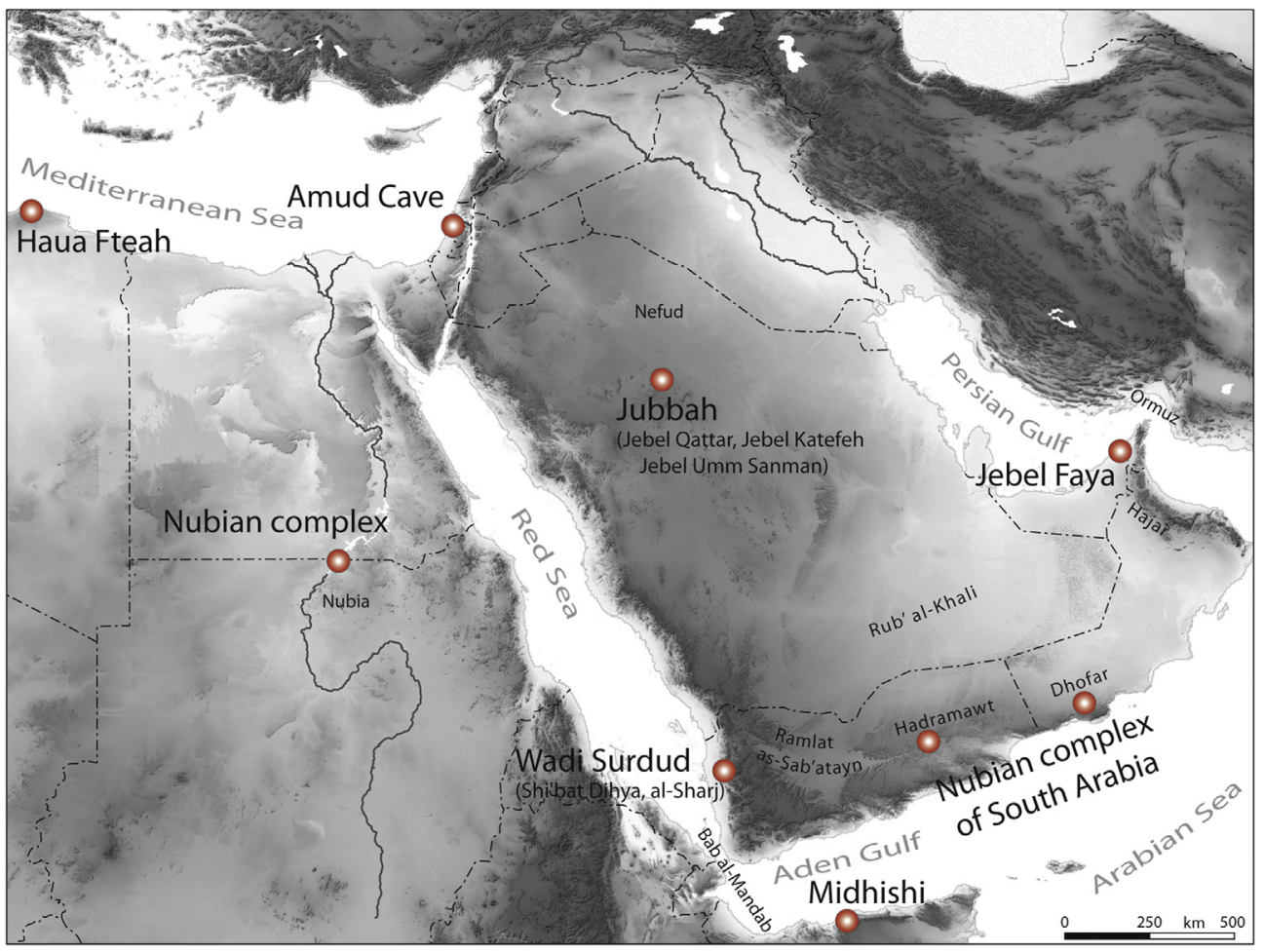

Fig. 1. Location of the archaeological sites and site complexes mentioned in the text; map adapted after Olivier Barge, service cartographique CNRS-MOM. 
392 m. Three sites (Shi'bat Dihya 1: SD1, Shi'bat Dihya 2: SD2, Al-Sharj1: AS1) have been investigated, ranging between ca. 60 and 50 ka (see Delagnes et al., 2012), and scattered lithics have been found in a lower geological unit dated to ca. $85 \mathrm{ka}$. The Wadi Surdud basin is part of the piedmont area of the highland western escarpment. It forms a topographic, climatic and bioenvironmental transitional zone between two highly contrasting areas (Fig. 2).

To the east, the Western Highlands form a range of steep mountains rising to $3000 / 3500 \mathrm{~m}$, with a peak at $3666 \mathrm{~m}$ asl, the highest point of Arabia. The current average annual rainfall increases gradually with altitude, up to $1000 \mathrm{~mm}$, and depends on two systems: the Red Sea Convergence Zone and the monsoonal Intertropical Convergence Zone (ITCZ), which are active in spring, summer, and autumn to a lesser extent (Farquharson et al., 1996). Wadi Surdud, as well as the six other major Wadi systems in the western highlands, drain west into the Red Sea, and have permanently flowing water in their upper reaches, while they retain water throughout the year in deep pools along their middle and lower reaches but their waters do not reach the Red Sea, except during rare periods of heavy rainfall (Scholte, 1992). The geology of these rocky mountains consists of a basement complex, sandstones and volcanics. They do not retain any Quaternary deposits.

To the west, the Tihama coastal plain corresponds to desert lowlands which stretch along the Yemeni Red Sea coast from the Bab al-Mandab strait to the Saudi Arabian border. The climate along the Red Sea is hot. The average annual rainfall falls below $100 \mathrm{~mm}$, and precipitation events are limited to sparse and high intensity storm rainfalls (Farquharson et al., 1996), with $80 \%$ of the annual rainfall received during the winter months. The coastal landscape is composed of high energy sandy or gravelly beaches backed by sand dunes and low cliffs. A significant part of the Red Sea rim is covered by well-developed mangroves. The mouths of the main wadis correspond to coastal mudflats with sub-surface seepage that creates richer habitats. There are no permanent sources of freshwater. The thick Holocene sand dunes that extend over most of the coastal plain completely cover all previous deposits.
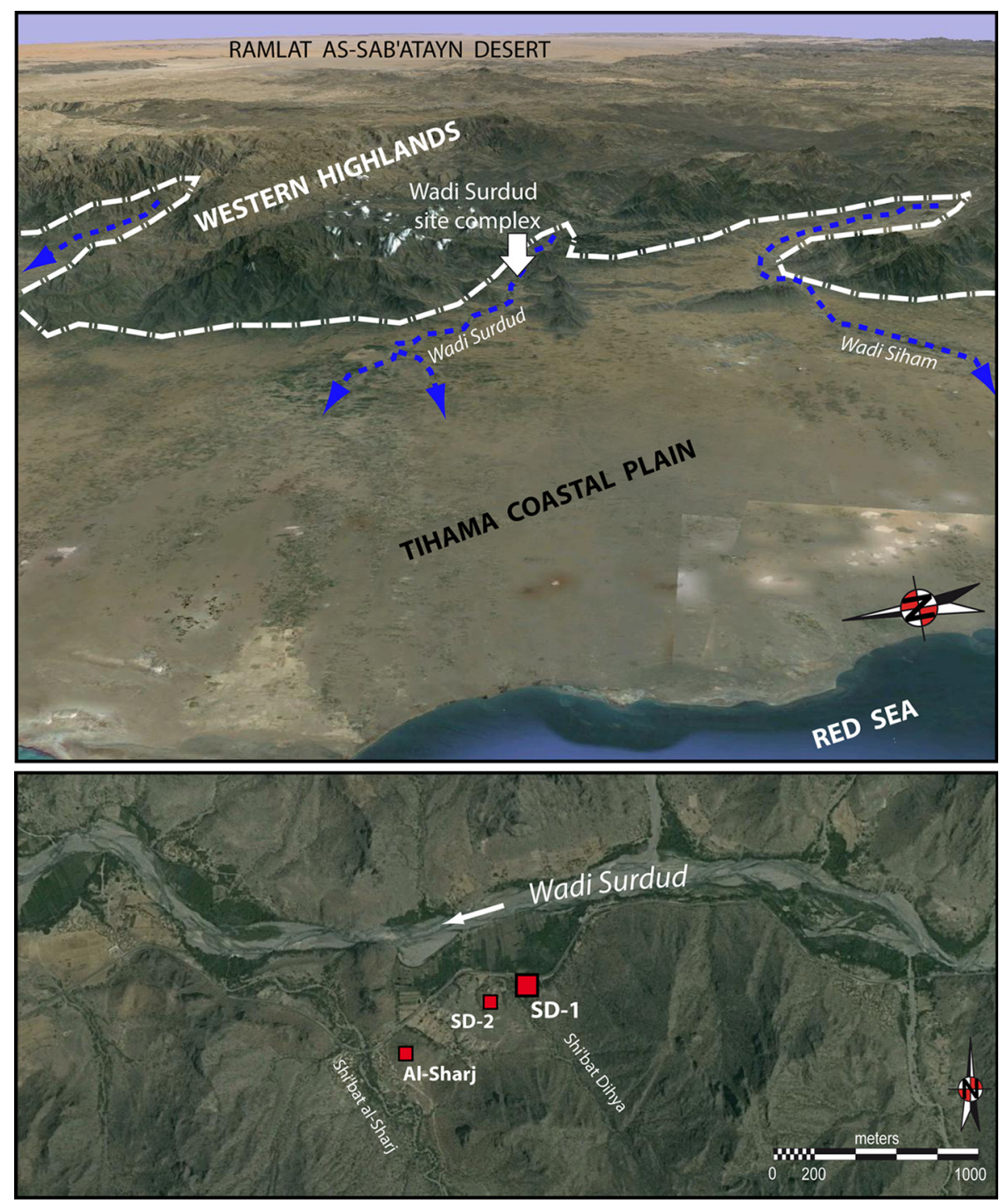

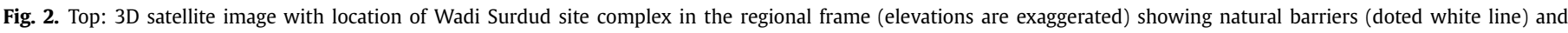
circulation ways (wadis and plain); Bottom: distribution of SD1, SD2 and AS1 within the Wadi Surdud basin; satellite imagery after Google Earth. 
The piedmont area forms a particularly favorable context for site preservation in contrast with the highlands and the coastal plain. This is mostly due to its topography and relief, with a series of escarpments encompassing internal sedimentary basins. It also constitutes one the most favorable habitats in Arabia. Permanent freshwater is available in the Wadi beds and rainfall is distributed over a significant part of the year, which is an essential parameter in a region where water resources are exclusively rainfall-dependent. The vegetation is rich and diversified, with a variety of palm trees, acacias, succulents and fruit trees in particular. The mammals range from low-land taxa to mountain species, including foxes, hares, crested porcupines, Hamadryas baboons, rock hyrax and gazelles, in association with a great variety of birds (Scholte, 1992). The ecological diversity of the region is related to its situation at the boundary between a mountainous ecozone and a desert coastal plain. Due to a high topographic relief, this particular ecozone may move up and down over a short distance along the altitudinal gradient (Basell, 2008). It thus provides in Arabia an exceptional situation of longterm resource and habitat availability, which has likely enabled stable human settlements over a significant part of the Pleistocene.

The natural pathways and barriers that may have determined human dispersal trajectories are key parameters for assessing Pleistocene settlement dynamics in this region, due to strong topographic contrasts. North-south displacements are easy along the flat coastal plain, but past human settlements in this area were presumably limited to humid periods due to the lack of permanent water resources. In the piedmont and highland areas, north-south displacements are very unlikely, considering the general orientation of the escarpments and the very steep mountain slopes. The natural pathways in these areas are westeast oriented, following the Wadi beds. The Wadi Surdud complex is located along one of these pathways. The question thus arises as to whether this natural pathway may have constituted one of the possible expansion routes across Arabia during the Upper Pleistocene. This hypothesis is highly unlikely given that the valley ends quite rapidly to the east, some $30 \mathrm{~km}$ upstream, where the highlands rise abruptly to some $2000 \mathrm{~m}$ asl. The natural pathways along the major Wadi drainages which spring up in the Western Highlands are all limited to the east by the natural barrier formed by the highland peaks. Further east, the highlands descend gradually to the interior plateau that holds the Ramlat as-Sab'atayn desert, a southwest portion of the vast Rub' al-Khali desert (the Empty Quarter), which has likely not constituted an attractive area for past populations. These specific topographic and environmental settings suggest that the natural pathways formed by the Wadi drainage in this part of Arabia led to cul-de-sac situations. They did not correspond to major expansion routes towards inland Arabia for past populations, but rather to favorable ecozones that may have drawn human groups over the long-term.

\section{Environmental context 55,000 years ago}

At the Wadi Surdud micro-regional scale, two main alluvial units visible on the left bank of Wadi Surdud provide a significant environmental record from the end of MIS 5 to the first part of MIS 3 (Sitzia et al., 2012). A total of 19 age estimates were obtained by Optically Stimulated Luminescence (OSL) on sediment samples (Fig. 3). The lower unit, or Al-Sharj Member, is dated to ca. $85 \mathrm{ka}$ (MIS 5) and has provided only a few nondiagnostic scattered artifacts. The upper unit, the Shi'bat Dihya Member, is a $30 \mathrm{~m}$ thick sequence dated between 63 and $42 \mathrm{ka}$

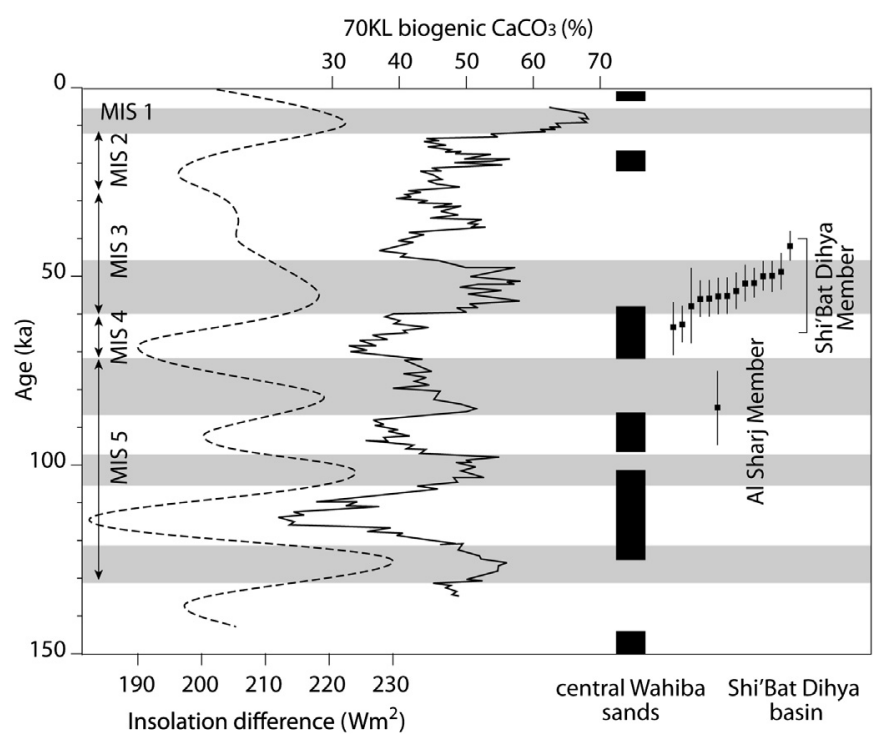

Fig. 3. Comparative chronology of the development of Shi'Bat Dihya and Al Sharj members (OSL dates from Delagnes et al., 2012) and the Wahiba sands of Oman (from Preusser, 2009). The content of biogenic $\mathrm{CaCO}_{3}$ in core $70 \mathrm{KL}$ is inversely correlated with the contribution of dust in the Arabian sea (from Leuschner and Sirocko, 2003); the curve of the summer insolation difference between $30^{\circ} \mathrm{S}$ and $30^{\circ} \mathrm{N}$ is a measure of the intensity of the Indian monsoon (from Leuschner and Sirocko, 2003); after Sitzia et al., 2012.

(MIS 3), that contains several dense Middle Paleolithic archaeological concentrations. Two of them were partially excavated between 2006 and 2008 as part of the Paleo-Y international project (Macchiarelli, 2009): Shi'bat Dihya 1 (SD1) and Shi'bat Dihya 2 (SD2). Both units are dominantly silty and interpreted as flood deposits over an alluvial plain (Reineck and Singh, 1980; Miall, 1996). The silty texture and the high accretion rate of the floodplain are thought to reflect intense redistribution by the Wadi of loess material provided by the coastal sand desert. Other more distant sources of loess such as the Rub' al Khali desert in the Arabian Peninsula (Crouvi et al., 2010) or East Africa (Middleton and Goudie, 2001) are also possibly involved. Coarsergrained lenses are locally intercalated in the sequence and correspond to secondary channels or crevasse splay deposits. The top of the Shi'Bat Dihya Member is capped by a desert pavement of iron-crusted cobble gravels.

Gypsum precipitation in the whole sequence and groundwater calcrete horizons suggest conditions of water balance deficit and high (seasonal) evaporation, and reveal that the environment contemporaneous with the human occupation was semi-arid to arid. This is in accordance with the faunal data, and in particular with the presence at SD1 of Equus sp. cf. E. hemionus, a taxon characteristic of arid steppe environments (Reading et al., 2001). Nevertheless, the Shi'bat Dihya alluvial formation was deposited at the beginning of MIS 3, which does not belong to the driest climatic phases of the Upper Pleistocene in the Arabian Peninsula (Fig. 3), but corresponds to a period of strengthened influence of the Indian summer monsoon (Clemens and Prell, 2003; Leuschner and Sirocko, 2003; Drake et al., 2013; Parton et al., 2013).

MIS 4 (74-60 ka) and MIS 2 (25-10 ka) have left almost no sedimentary record in the Wadi Surdud basin. These stages correspond to hyperarid episodes with subsequent cessation of alluvial sedimentation and formation of desert pavements. The incision phases in the basin that separate the different sedimentary members are assumed to result from high water flux periods in the 
Wadi, corresponding to the humidity peaks documented during MIS 5e (128-120 ka), MIS 5c (110-100 ka) and MIS 5a (90-74 ka) in the Arabian Peninsula, as well as during the beginning of the Holocene (Fleitmann and Matter, 2009; Fleitmann et al., 2011; Rosenberg et al., 2011). The palaeoenvironmental data thus show that the Middle Paleolithic sites of SD1 and SD2 result from human occupations in an alluvial plain that was subject to periodic flooding in a (semi-) arid environment, with the persistence of at least seasonal water pools in the Wadi bed, as indicated by the algal origin of the organic matter preserved in the flood deposits (Sitzia et al., 2012).

\section{A local Middle Paleolithic tradition}

Two significant lithic samples have been collected at SD1 and SD2, along Shi'bat Dihya stream, some $200 \mathrm{~m}$ above its confluence with Wadi Surdud. Both sites are characterized by a single dense archaeological horizon, some $10-20 \mathrm{~cm}$ thick. SD1 was excavated in 2006 and 2008 over a surface of $25 \mathrm{~m}^{2}$, corresponding to the western margin of the human occupation (Delagnes et al., 2012). It has currently yielded the most significant archaeological assemblage of the Wadi Surdud complex, with a lithic sample of 5488 elements greater than $2 \mathrm{~cm}$ and nearly 25,000 lithic remains less than $2 \mathrm{~cm}$ (82\% of the assemblage). They are associated with a small faunal sample consisting of 97 anatomically and taxonomically identified faunal remains. Fire-related activities were performed at SD1, indicated by a number of burnt lithic pieces and small pieces of charcoal dispersed in and around rings of burnt sediment.

At SD2, a large sample (1336 lithics and 1 bone fragment) has been collected from a collapsed block of sediment containing a portion of the archaeological material in its primary context. At both sites, the physical preservation of the lithic material is homogeneous and excellent, with no patina and surface abrasion, and no or very limited edge damage. Faunal fragments have been subjected to post-depositional chemical alterations, resulting in the selective preservation of the dental remains (54\% of the faunal elements in SD1 are teeth or teeth fragments). Al-Sharj stream, parallel to Shi'bat Dihya some $150 \mathrm{~m}$ westward, also exhibits a series of archaeological spots (AS1, AS2). The Wadi Surdud archaeological occurrences belong to at least four successive phases of human occupation, all related to the Middle Paleolithic. Stratigraphically, SD1 is $7 \mathrm{~m}$ below SD2, which is $6 \mathrm{~m}$ below AS1. Whereas it is quite difficult to estimate the time lapse separating these successive hominid occupations, they could range within a short time period, around $55 \mathrm{ka}$, as suggested by the rapid accretion rate of the Wadi Surdud basin. The SD1 lithic record (Fig. 4 ) is characterized by a set of technological features, which are:

(1) a local procurement of Wadi pebbles with a marked selectivity of rhyolite angular pebbles (93.8\%);

(2) a prevalent production of pointed and elongated flakes and blades (Fig. 4) using a hard hammer percussion technique, from minimally prepared convergent unidirectional and blade cores. Despite a significant ratio of fragmented pieces, these pointed items do not exhibit projectile diagnostic fractures and they likely correspond to cutting tools;

(3) a very low ratio of retouched pieces $(0.5 \%)$;

(4) the manufacturing of a small series of worked pebbles $(N=9)$ with long and sinuous blunt edges formed by a series of unifacial invasive removals;
(5) a composition proceeding from a complete reduction sequence performed on the spot during a phase of occupation devoted to multi-purpose activities.

The more recent archaeological record from SD2 exhibits some common features, i.e. the absence of formal retouched tools and the presence of a significant proportion of blades and pointed flakes, although significantly lower than at SD1. However, the flaking methods performed on the spot differ radically compared with SD1, resulting in a prevalence of unprepared discoidal-like cores and quadrangular short flakes with frequent cortical platform and distal edges (Fig. 5).

The question as to whether the partial similarities between the Wadi Surdud sites relate to an in-situ evolution still has to be tested by in-depth investigations at a local scale, including the extensive excavation of SD2 and AS1 sites. At this stage, it is nevertheless possible to argue that the Middle Paleolithic tradition evident at both SD1 and SD2 does not directly conform to any contemporaneous Middle Paleolithic or Middle Stone Age cultures from either the Levant, East Africa or even Arabia. In both sites, the Levallois debitage plays a secondary role, the rare retouched tools are unformal and expedient, and the blade production which prevails at SD1 is significantly less sophisticated than the blade/bladelet productions documented in the Late Levantine Mousterian (Monigal, 2001) and in the East African Late Middle Stone Age (McBrearty and Brooks, 2000; McBrearty, 2003). Both SD1 and SD2 also lack the normative toolkit of the Levantine assemblages. A production of blades and elongated points using simple core reduction strategies, similar to the main reduction sequence evidenced at SD1, is found in the Early Levantine Mousterian (Meignen, 2000; Monigal, 2001), which predates the Wadi Sudurd site complex by more than 100,000 years. The discrepancy with the East African Middle Stone Age is still more pronounced: with few exceptions, e.g. Midhishi 2 (Gresham, 1984), the recurrent unidirectional convergent methods - Levallois or non-Levallois - are not a prevalent feature. Moreover, the specific toolkit of the East African Middle Stone Age, i.e. unifacial and bifacial points (Clark, 1988; McBrearty and Brooks, 2000), is absent from the Wadi Surdud complex. Finally, SD2 exhibits a discoidal flaking system which is neither time nor space restricted and never prevalent in either the Levantine or East African records. The idiosyncratic meaning of the Wadi Surdud assemblages also holds true at the scale of the southern Arabian Peninsula, where a large majority of the Middle Paleolithic assemblages are based on the Levallois debitage (Inizan and Ortlieb, 1987; Crassard, 2008; Crassard, 2009; Crassard and Thiébaut, 2011; Rose et al., 2011; Usik et al., 2013).

\section{Discussion}

\subsection{MIS 5 inter-regional expansions}

Over the last few years, a set of new archaeological data has provided significant evidence for the understanding of hominid dispersals toward and across Arabia during MIS 5 (130-74 ka). The site of Jebel Faya NE-1 in the Emirate of Sharjah (United Arab Emirates) has yielded stratified lithic industries, including assemblage "C" dated to ca. 125 ka (Armitage et al., 2011). It has been proposed that the lithic technology (Levallois debitage, thickbifacial "foliates") highly resembles the East African Middle Stone Age, suggesting a rapid dispersal across the Bab al-Mandab Strait, along the Arabian Sea rim and up to the Strait of Hormuz leading to the rest of Central and South Asia. 

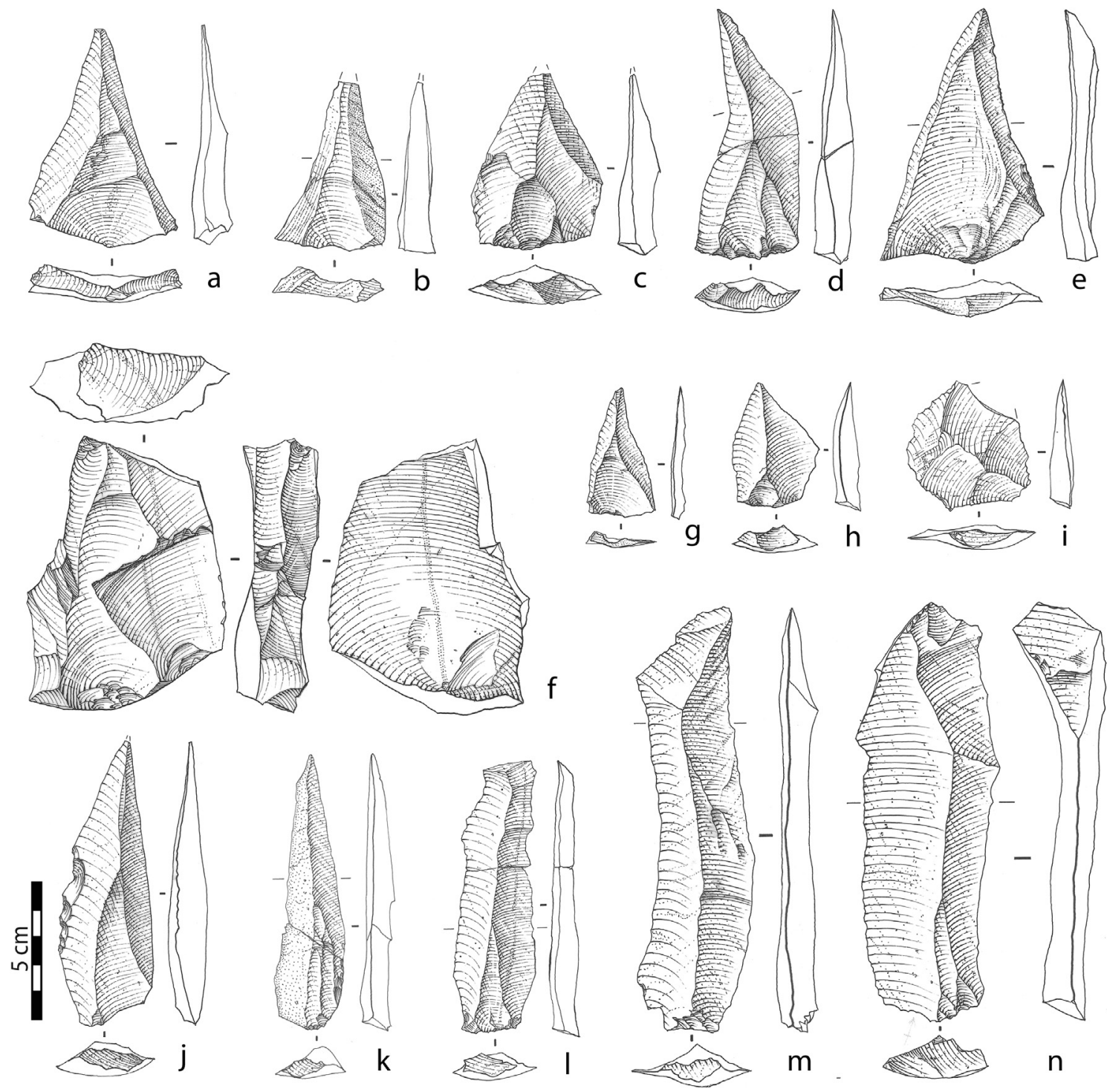

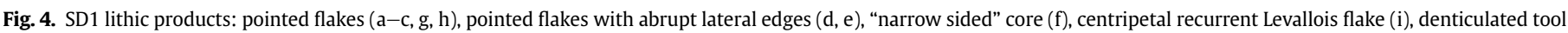
(j), cortical blade (k), thin and rectilinear blade (l), large thick blades (m, n); drawings by J. Jaubert, after Delagnes et al., 2012.

A similar expansion model is suggested by another line of evidence, from the Dhofar region (Oman), where a number of stratified and surface sites clearly attest the use of a Nubian (Type 1 and 2) Levallois technology (Rose et al., 2011; Usik et al., 2013). This technology was formerly known in South Egypt, North Sudan, and more sporadically in Ethiopia (Guichard and Guichard, 1965; Van Peer, 1992). In Arabia, other previous discoveries in Central and Eastern Yemen (notably in Hadramawt) had revealed the same technological patterns which can now be related to the Nubian complex of South Arabia (Inizan and Ortlieb, 1987; Crassard, 2008, 2009; Crassard and Thiébaut, 2011). Whereas this complex provides convincing evidence of an African AMH influx into Arabia, the question of the destination and fate of the AMHs who brought the Nubian technology to southern Arabia still has to be addressed. The data from both Jebel Faya and the Nubian complex from South Arabia are nevertheless consistent with a significant AMH expansion out of Africa along a Southern Arabian corridor as early as the beginning of MIS 5.
An alternative expansion model during the early Middle Paleolithic has been recently proposed (Petraglia, 2011), partly as a result of the investigations carried out at Jubbah in Northern Saudi Arabia (Petraglia et al., 2011, 2012). The presence of lakes and rivers in the Arabian Peninsula during MIS 5, as evident at Jubbah, would have facilitated multidirectional migrations and expansions of AMH groups across inland areas, "perhaps even leading to interbreeding with Neanderthals in northern areas" (Petraglia, 2011: 51). These new data give a more complex picture of the human settlement dynamics in Arabia, in particular during the wet phases driven by the North-South migration of the ITCZ, when a greater amount of biomass would have survived, changing the arid steppes and deserts of Arabia in open and semi-arid savannahs (Rosenberg et al., 2011). Conversely, the hyper-arid phases would have resulted in the extinction of the Arabian populations (McClure, 1971; Petraglia and Alsharekh, 2003; Rose, 2007b; Preusser, 2009; Rosenberg et al., 2012). This scenario could have repeatedly occurred throughout the Pleistocene, and in particular during the hyper-arid events of MIS 4, a period which has not 


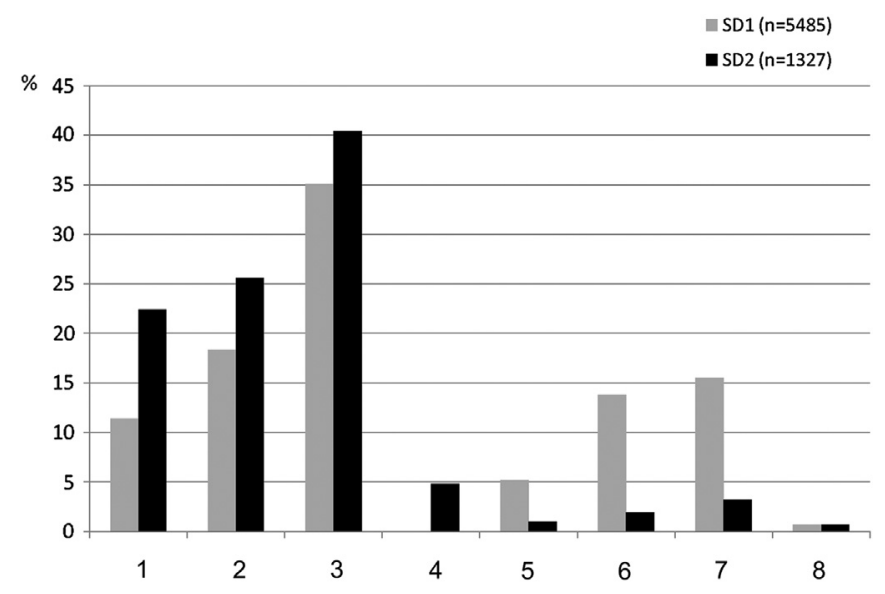

Fig. 5. Lithic composition of SD2 compared to SD1, based on the main categories of end-products and by-products (lithics $<2 \mathrm{~cm}$; worked and unworked pebbles not included), 1: debris/fragments, 2: cortical flakes, 3: undifferentiated flakes, 4: thick quadrangular flakes; 5: pointed flakes, 6: Levallois-like flakes, 7: blades, 8: cores.

yielded so far any evidence of human presence in the entire peninsula. A discontinuous occupation of the Arabian Peninsula during the Middle Paleolithic is also suggested by a high technological diversity (Petraglia and Alsharekh, 2003; Rose, 2007a; Crassard, 2008; Petraglia and Rose, 2009; Delagnes et al., 2012) whose significance (diachronic changes vs. regional synchronic diversity) remains however questionable since it relies on few dated and stratified records. In between periods of moisture and hyper-aridity peaks, the Arabian populations endured a series of climate and environmental degradations which may have resulted in contractions of settlements into environmental refugia (Bailey, 2009; Rose and Petraglia, 2009; Rose, 2010). This environmental refugia model is prominent in the literature relating to the East African Middle Stone Age (Clark, 1989; Lahr and Foley, 1994; Ambrose, 1998; Basell, 2008), and is discussed in the context of the Azraq Basin in Jordan by Cordova et al. (2013), but remains largely theoretical in the Arabian Peninsula during MIS 5, due the lack of chronological and environmental data from stratified archaeological contexts.

\subsection{MIS 3 regional contractions}

By contrast with the record currently available for MIS 5, it seems that a major phase of population contraction occurred in the Arabian Peninsula at the beginning of MIS 3. During this time period, the Wadi Surdud basin appears to have served as a refugium. This interpretation is based on the succession of at least three phases of human occupation (SD1, SD2, AS1) at a microregional scale ca. 55-50 ka, a semi-desert paleoenvironmental record, a context of favorable habitat that maintained stable water and animal resources over the long-term, together with the development of a local Middle Paleolithic tradition. In the entire Arabian Peninsula, such a situation is only echoed at Jebel Faya (assemblages A and B) in the foothills of the Hajjar Mountains (Armitage et al., 2011), which also encompasses a succession of at least two human occupations dated to MIS 3 assigned to a local Middle Paleolithic tradition. The paleoenvironments contemporaneous with the successive phases of occupations at Jebel Faya are discussed by Bretzke et al. (2013).

Some remote technological affinities exist between SD1 and Jebel Faya - assemblage B, based on the combined production of blades, pointed blades and flakes with a variety of core reduction strategies. Similar technological patterns are described in a number of penecontemporaneous sites dispersed in neighboring areas. These sites are in particular Midhishi 2 - CSUc in Somalia (Gresham, 1984), Amud Cave - B1 in Israel (Hovers, 1998), and Haua Fteah - XXX-XXXII in Lybia (McBurney, 1967; Moyer, 2003). Beyond their technological affinities (Table 1), they all lie in circumscribed favorable ecozones characterized by present mean annual rainfalls which are significantly higher (>200 mm) than the surrounding desert or semi-desert areas. They form core areas where the late Middle Paleolithic or late Middle Stone Age groups likely contracted, before expanding again according to a "push and pull" process when more favorable climate conditions followed, or before extinction when conditions deteriorated. If both scenarios are plausible and may have occurred alternately, it seems most likely that the whole Arabian Peninsula was depopulated during the harshest periods of MIS 4, MIS 3 and MIS 2 and that the whole region has experienced demographic discontinuities similar to that in Northern Europe, with "source and sink" demographic patterns (Dennell et al., 2011).

This questions the origin of the human groups who occupied the Arabian Peninsula at the beginning of MIS 3. Did they form a remnant population that survives the hyper-arid peaks of MIS 4, either in Arabia or at its periphery? Or did they come from elsewhere? There is not so far any clear evidence of population continuity between the end of MIS 5 and the beginning of MIS 3, but data coverage is still too weak to answer this question. So far a migration flow across southern Arabia ca. 60-50 ka of African AMH groups introducing a number of technological and symbolic innovations in Eurasia, as speculated by the Out of Africa 3 model (Mellars, 2006), is not supported by any archaeological evidence. The populations who were present in southern Arabia at the beginning of MIS 3, at Wadi Surdud and Jebel Faya (A and B) in particular, do not appear to have introduced new behavioral skills into the region. Complex lithic and symbolic productions, in the form of standardized lithic artifacts, composite hafting systems, bone implements, personal ornaments, pigments or symbolic items are as yet unreported in Arabia over the entire Middle Paleolithic period.

Conversely, the picture emerging from the most recent data from Arabia (Armitage et al., 2011; Petraglia et al., 2011, 2012; Rose et al., 2011; Usik et al., 2013) favors the scenario of major expansion waves from Africa, and maybe from elsewhere, during the humid phases of MIS 5. This is in line with a number of paleoenvironmental factors combined with site distribution in East Africa during the early Middle Stone Age, which suggest that Homo sapiens spread in and out of East Africa during MIS 5 (Basell, 2008). Although the documentation related to the beginning of MIS 3 is still very scarce in the Saharo-Arabian Arid Belt, it seems most likely that this period has been dominated by contractions of populations into disconnected areas which would have served as environmental refugia. Archaeologically, this assumption is supported by an increased regional diversity. This is visible to some extent in and around southern Arabia with the development of local traditions. Such a development of regional identities during the late Middle Stone Age has long been evidenced in East-Africa (Clark, 1988). Such a mosaic of stylistic features is reflected by a variety of end-products and formal tool types among the main Levantine and East-African sites correlated with MIS 3, while a number of technological affinities, e.g. the predominance of the Levallois unidirectional convergent flaking method, persist between sites (Table 1 ). 
Table 1

Technological and typological attributes from the main Levantine, Arabian and East-African assemblages dated between 100 and 50 ka (1. Henry, 1995; 2. Munday, 1977; 3. Ohnuma and Akazawa, 1988; 4. Hovers, 1998; 5. Meignen and Bar Yosef, 1992; 6. Valladas et al., 1998; 7. Delagnes et al., 2012; 8. Pleurdeau, 2005; 9. Yellen et al., 2005; 10. Brandt, 1986; 11. Brandt and Gresham, 1989; 12. Brandt et al., 2012; 13. Kurashina, 1978).

\begin{tabular}{|c|c|c|c|c|c|c|}
\hline Site & Age (ka BP) & Prevalent flaking methods & $\begin{array}{l}\text { End-products (dominant platform } \\
\text { type) }\end{array}$ & $\begin{array}{l}\% \text { of retouched } \\
\text { or shaped tools }\end{array}$ & Main formal tool types & Stylistic features \\
\hline Tor Faraj - Mid C (Jordan) ${ }^{1}$ & $\sim 69$ to 44 & $\begin{array}{l}\text { Levallois unidirectional, convergent } \\
\text { and bidirectional }\end{array}$ & $\begin{array}{l}\text { Levallois points (multiple, or faceted: } \\
80.2 \% \text { ), blades (multiple or faceted: } \\
31.8 \% \text { ) }\end{array}$ & 1.9 & $\begin{array}{l}\text { Levallois retouched } \\
\text { points, retouched pieces, } \\
\text { notches }\end{array}$ & $\begin{array}{l}\text { Levallois points, inverse } \\
\text { retouch, Nahr-Ibrahim }\end{array}$ \\
\hline Tor Sahiba $-\mathbf{C}(\text { Jordan })^{1}$ & $\sim 69$ & $\begin{array}{l}\text { Levallois unidirectional, convergent } \\
\text { and bidirectional }\end{array}$ & $\begin{array}{l}\text { Levallois points (multiple or faceted } \\
54.2 \% \text { ), blades (single } 39.4 \% \text { ) }\end{array}$ & 1.4 & $\begin{array}{l}\text { Levallois retouched points, } \\
\text { retouched pieces, denticulates } \\
\text { and notches }\end{array}$ & $\begin{array}{l}\text { Levallois points, inverse } \\
\text { retouch }\end{array}$ \\
\hline $\begin{array}{l}\text { Nahal Aqev (D35) - 3e } \\
\quad \text { (Jordan) })^{2}\end{array}$ & $\sim 85$ to 74 & $\begin{array}{l}\text { Levallois unidirectional and } \\
\text { bidirectional, irregular Levallois } \\
\text { and non-Levallois single platform }\end{array}$ & $\begin{array}{l}\text { Levallois and non-Levallois blades, } \\
\text { Levallois flakes (complex or faceted: } \\
66.2 \% \text { ) }\end{array}$ & 8.2 & $\begin{array}{l}\text { Notched pieces, sidescrapers, } \\
\text { burins }\end{array}$ & $\begin{array}{l}\text { Nahr Ibrahim, burins, light, } \\
\text { flat and invasive retouch }\end{array}$ \\
\hline Amud Cave - B4 (Israel) $)^{3,4}$ & $\sim 65$ to 55 & Levallois unidirectional convergent & $\begin{array}{l}\text { Elongated Levallois points and } \\
\text { triangular flakes (dihedral, faceted) }\end{array}$ & 4.6 & Fractured pieces, burins & $\begin{array}{l}\text { Fractured pieces: "éclats à } \\
\text { chanfrein", burins, elongated } \\
\text { Levallois points }\end{array}$ \\
\hline $\begin{array}{l}\text { Kebara Cave - XII-XI } \\
\quad(\text { Israel })^{5,6}\end{array}$ & $\sim 60$ & $\begin{array}{l}\text { Levallois unidirectional, convergent } \\
\text { and bidirectional }\end{array}$ & $\begin{array}{l}\text { Levallois sub-triangular flakes, blades } \\
\text { (faceted } 83.3 \text { and } 64.1 \% \text { ) }\end{array}$ & $3.1-4.4$ & $\begin{array}{l}\text { Sidescrapers, partially } \\
\text { retouched pieces }\end{array}$ & $\begin{array}{l}\text { Nahr Ibrahim, burins, inverse } \\
\text { retouch, Levallois points with } \\
\text { "chapeau de gendarme" butts } \\
\text { and "concorde" profiles }\end{array}$ \\
\hline SD $1^{7}$ & $\sim 55$ & $\begin{array}{l}\text { Blade, Levallois unidirectional } \\
\text { convergent }\end{array}$ & $\begin{array}{l}\text { Blades, pointed blades (plain: 51\%), } \\
\text { points, Levallois points (plain: 54\%), } \\
\text { Levallois flakes (plain: 55\%) }\end{array}$ & 0.5 & Denticulates and notches & Pointed blades and flakes \\
\hline SD $2^{7}$ & $\sim 55$ & Discoidal & Discoidal flakes & 0 & - & Discoidal flakes \\
\hline Porc-Epic Cave (Ethiopia) ${ }^{8}$ & $\sim 71$ to $61(?)$ & $\begin{array}{l}\text { Levallois preferential; Levallois } \\
\text { recurrent (unidirectional, orthogonal } \\
\text { radial), discoidal, prismatic }\end{array}$ & $\begin{array}{l}\text { Levallois flakes, flakes, blades and } \\
\text { bladelets, rare Levallois points }\end{array}$ & 8 & $\begin{array}{l}\text { Unifacial and bifacial points, } \\
\text { scrapers, notches and } \\
\text { denticulates }\end{array}$ & $\begin{array}{l}\text { Backed bladelets and } \\
\text { geometrics }\end{array}$ \\
\hline Aduma - Arbu B (Ethiopia) ${ }^{9}$ & $\sim 100$ to 80 & $\begin{array}{l}\text { Levallois, Levallois-blade and micro- } \\
\text { Levallois }\end{array}$ & Levallois flakes, blades and bladelets & 1.4 to 4.4 & $\begin{array}{l}\text { Unifacial and bifacial points, } \\
\text { retouched flakes and blades, } \\
\text { scrapers, }\end{array}$ & $\begin{array}{l}\text { Micro-cores, small obsidian } \\
\text { scrapers and points, perforators } \\
\text { and borers }\end{array}$ \\
\hline Midhishi 2 (Somalia) $)^{10,11}$ & $\sim 90$ to 40 (?) & Levallois, discoidal, blade & $\begin{array}{l}\text { Levallois points, pointed flakes, large } \\
\text { blades }\end{array}$ & 4 & $\begin{array}{l}\text { Scrapers, unifacial and bifacial } \\
\text { points }\end{array}$ & Levallois points \\
\hline $\begin{array}{l}\text { Mochena Borago } \\
\text { Rockshelter - Lower } \\
\text { T-Group (Ethiopia) })^{12}\end{array}$ & $>53$ & $\begin{array}{l}\text { Tabular-shaped single, double and } \\
\text { multi-platform cores }\end{array}$ & Ovate to elongated flakes & 2 & $\begin{array}{l}\text { Unifacial and bifacial points, } \\
\text { scrapers and burins }\end{array}$ & Unifacial and bifacial points \\
\hline $\begin{array}{l}\text { Koné }-5 \text { extension } \\
\quad(\text { Ethiopia })^{10,13}\end{array}$ & $>60(?)$ & Nubian (type I) and Levallois & $\begin{array}{l}\text { Levallois flakes (faceted: } 76 \% \text { ), } \\
\text { Levallois points (faceted: } 88.9 \% \text { ) }\end{array}$ & 0.5 & $\begin{array}{l}\text { Notched and denticulate } \\
\text { scrapers, burins, unifacial and } \\
\text { bifacial points }\end{array}$ & $\begin{array}{l}\text { Nubian cores and points, sinew } \\
\text { frayers }\end{array}$ \\
\hline
\end{tabular}




\section{Conclusion}

At a micro-regional scale, the Wadi Surdud basin presents a conjunction of topographic, ecological, paleoenvionmental and archaeological features which are consistent with an interpretation of it as a refugium for MIS 3 groups. The piedmont of the Yemeni Western Highlands is among the rare areas in Arabia that might have provided habitat and resource stability during the arid phases of the Pleistocene, while it is very likely that the rest of the peninsula was aridified ca. 60-50 ka, with the exception of few disconnected source regions, such as the Sharjah hills sand and maybe the Dhofar Mountain. It seems also that the groups who occupied this refugium became increasingly isolated over time, as suggested by the shifts from SD1 to SD2. This aridification might have lasted over a long time period, supposedly during the second half of MIS 3 and part of MIS 2, as no Upper Paleolithic has ever been clearly identified in the entire Arabian Peninsula.

A time and space fragmentation of the occupation of the SaharoArabian arid belt during the Pleistocene, combined with multidirectional influxes of populations, lead to new alternative scenarios of population dynamics across, but also inside Arabia throughout the Pleistocene. A set of high-resolution archaeological contexts recently discovered in the Arabian Peninsula suggests that the major human expansion waves which occurred in the region during the Upper Pleistocene are correlated with the wet phases of MIS 5. Conversely, the beginning of MIS 3 would rather fit in the region with contractions of populations into a few refugia areas. While the precise role played by the Arabian Peninsula in the major expansion waves from Africa to Eurasia still has to be more accurately defined, it makes no doubt anymore that the region has developed its own local traditions, at different time periods and in distinct source regions. These non-linear patterns of cultural and demographic evolution question the timing and route commonly proposed for the expansion of $H$. sapiens out of Africa.

\section{Acknowledgements}

We wish to thank the whole Paleo-Y team for the tremendous interdisciplinary studies that have been carried out over the last few years, and in particular Roberto Macchiarelli (University of Poitiers and Muséum National d'Histoire Naturelle, France) who has led the Paleo-Y international research project since 2005, in collaboration with the Yemeni General Organization for Antiquities and Museums. With special reference to the present study, we warmly thank for their kind suggestions and valuable discussions Michel Brenet, Marie-Louise Inizan, Jacques Jaubert, Michael Petraglia and Jeffrey Rose. We wish to thank James Blinkhorn and Huw Groucutt for inviting us to the conference "The Middle Palaeolithic in the desert" in Oxford where a paper upon which the present piece is based was presented. This article is finally greatly indebted to Huw Groucutt and two anonymous reviewers for their useful comments and editing help.

\section{References}

Ambrose, S., 1998. Late Pleistocene human population bottlenecks, volcanic winter, and differentiation of modern humans. Journal of Human Evolution 34, 623-651.

Amirkhanov, H., 1994. Research on the Palaeolithic and Neolithic of Hadhramaut and Mahra. Arabian Archaeology and Epigraphy, 217-228.

Armitage, S.J., Jasim, S.A., Marks, A.E., Parker, A.G., Usik, V.I., Uerpmann, H.P., 2011. The southern route "Out of Africa": evidence for an early expansion of modern humans into Arabia. Science 331, 453-456.

Bailey, G., 2009. The Red Sea, coastal Landscapes, and hominin dispersals. In: Petraglia, M.D., Rose, J.J. (Eds.), The Evolution of Human Populations in Arabia. Paleoenvironments, Prehistory and Genetics. Springer, London, pp. 15-37.
Bailey, G., Flemming, N., King, G., Lambeck, K., Momber, G., Moran, L., ALSharekh, A., Vita-Finzi, C., 2007. Coastlines, submerged landscapes, and human evolution: the Red Sea Basin and the Farasan Islands. Journal of Island and Coastal Archaeology 2 (2), 127-160.

Basell, L.S., 2008. Middle Stone Age (MSA) site distributions in eastern Africa and their relationship to Quaternary environmental change, refugia, and the evolution of Homo sapiens. Quaternary Science Reviews 27, 2484-2498.

Brandt, S.A., 1986. The Upper Pleistocene and early Holocene prehistory of the Horn of Africa. The African Archaeological Review 4, 41-82.

Brandt, S.A., Gresham, T.H., 1989. l'Âge de la Pierre en Somalie. L'Anthropologie 94 459-482.

Brandt, S.A., Fischer, E., Hildebrand, E.A., Vogelsang, R., Ambrose, S.H., Lesur, J., Wang, H., 2012. Early MIS 3 occupation of Mochena Borago Rockshelter, southwest Ethiopian highlands: implications for Late Pleistocene archaeology, paleoenvironments and modern human dispersals. Quaternary International 274, 38-54.

Bretzke, K., Armitage, S., Parker, A., Walkington, H., Uerpmann, H.P., 2013. The environmental context of Paleolithic settlement at FAY-NE1, Emirate Sharjah, UAE. Quaternary International 300, 83-93.

Caton-Thompson, G., 1938. Geology and archaeology of the Hadramaut, Southern Arabia. Nature 142, 139-142.

Caton-Thompson, G., 1953. Some Palaeoliths from south Arabia. Proceedings, Prehistory Society 19, 189-218.

Clark, J.D., 1988. The middle stone age of east Africa and the beginnings of regional identity. Journal of World Prehistory 2, 235-305.

Clark, J.D., 1989. The origins and spread of modern humans: a broad perspective on the African evidence. In: Mellars, P., Stringer, C. (Eds.), The Human Revolution: Behavioural and Biological Perspectives on the Origins of Modern Humans. Edinburgh University Press, Edinburgh, pp. 565-587.

Clemens, S.C., Prell, W.L., 2003. A 350,000 year summer-monsoon multi-proxy stack from the Owen Ridge, northern Arabian Sea. Marine Geology 201, 35-51.

Crassard, R., 2008. La préhistoire du Yémen. Diffusions et diversités locales, à travers l'étude d'industries lithiques du Hadramawt. Archaeopress, Oxford.

Crassard, R., 2009. Middle Paleolithic in Arabia: the view from the Hadramawt region, Yemen. In: Petraglia, M.D., Rose, J.I. (Eds.), The Evolution of Human Populations in Arabia. Paleoenvironments, Prehistory and Genetics. Springer Academic Publishers, London, pp. 151-168.

Crassard, R., Thiébaut, C., 2011. Levallois points production from eastern Yemen and some comparisons with assemblages from East-Africa, Europe and the Levant. In: Le Tensorer, J.M., Jagher, R., Otte, M. (Eds.), The Lower and Middle Paleaoloithic in the Middle East and Neighboring Regions. ERAUL, Liège, pp. 131-142.

Crouvi, O., Amit, R., Enzel, Y., Gillespie, A.R., 2010. Active sand seas and the formation of desert loess. Quaternary Science Reviews 29, 2087-2098.

Cordova, C.E., Nowell, A., Bisson, M., Ames, C.J.H., Poines, J., Chang, M., al-Nahar, M., 2013. Interglacial and glacial desert refugia and the Middle Palaeolithic of the Azraq Oasis, Jordan. Quaternary International 300, 94-110.

Delagnes, A., Tribolo, C., Bertran, P., Brenet, M., Crassard, R., Jaubert, J., Khalidi, L., Mercier, N., Nomade, S., Peigné, S., Sitzia, L., Tournepiche, J.F., Al-Halibi, M., AlMosabi, A., Macchiarelli, R., 2012. Inland human settlement in southern Arabia 55,000 years ago. New evidence from the Wadi Surdud Middle Paleolithic site complex, western Yemen. Journal of Human Evolution 63 (3), 452-474.

Dennell, R., Martinon-Torres, M., Bermudez de Castro, J.M., 2011. Hominin variability, climatic instability and population demography in Middle Pleistocene Europe. Quaternary Science Reviews 30, 1511-1524.

Drake, N.A., Breeze, P., Parker, A.G., 2013. Palaeoclimate in the Saharan and Arabian deserts during the Middle Palaeolithic and the potential for hominin dispersals. Quaternary International 300, 48-61.

Farquharson, F.A.K., Plinston, D.T., Sutcliffe, J.V., 1996. Rainfall and runoff in Yemen. Hydrological Sciences 41, 797-811.

Fleitmann, D., Burns, S., Pekala, M., Mangini, A., Al-Subbary, A., Al-Aowah, M., Kramers, J., Matter, A., 2011. Holocene and Pleistocene pluvial periods in Yemen, southern Arabia. Quaternary Science Reviews 30, 783-787.

Fleitmann, D., Matter, A., 2009. The speleothem record of climate variability in Southern Arabia. Comptes Rendus Geoscience 341, 633-642.

Forster, P., Matsumura, S., 2005. Did early humans do north or south? Science 308, 965-966.

Gresham, T.H., 1984. An Investigation of an Upper Pleistocene Archaeological Site in Somalia. University of Georgia, Athens.

Groucutt, H.S., Petraglia, M.D., 2012. The prehistory of the Arabian Peninsula: deserts, dispersals and demography. Evolutionary Anthropology 21, 113-125.

Guichard, J., Guichard, G., 1965. The Early and Middle Palaeolithic of Nubia: a preliminary report. In: Wendorf, F. (Ed.), Contributions to the Prehistory of Nubia. SMU Press, Dallas, pp. 57-116.

Henry, D.O. (Ed.), 1995. Prehistoric Cultural Ecology and Evolution. Insights from Southern Jordan Plenum Press, New York and London.

Hovers, E., 1998. The lithic assemblages of Amud Cave. In: Akazawa, T., Aoki, K., BarYosef, O. (Eds.), Neanderthals and Modern Humans in Western Asia. Plenum Press, New-York, pp. 143-163.

Inizan, M.L., Ortlieb, L., 1987. Préhistoire dans la région de Shabwa au Yémen du Sud (R.D.P. Yémen). Paléorient 13, 5-22.

Kurashina, H., 1978. An Examination of Prehistoric Lithic Technology in East-Central Ethiopia. University of California, Berkeley, Ph.D. dissertation.

Lahr, M.M., Foley, R., 1994. Multiple dispersals and modern human origins. Evolutionary Anthropology, 48-60. 
Lahr, M.M., Foley, R., 1998. Towards a theory of modern human origins: geography demography and diversity in recent human evolution. Yearbook of Physical Anthropology, 137-176.

Lambeck, K., Purcell, A., Flemming, N.C., Vita-Finzi, C., Alsharekh, A.M., Bailey, G.N. 2011. Sea level and shoreline reconstructions for the Red Sea: isostatic and tectonic considerations and implications for hominin migration out of Africa. Quaternary Science Reviews 30, 3542-3574.

Leuschner, D.C., Sirocko, H., 2003. Orbital insolation forcing for the Indian Monsoon - a motor for global climate changes? Palaeogeography, Palaeoclimatology, Palaeoecology 197, 83-95.

Macaulay, M., Hill, C., Achilli, A., Rengo, C., Clarke, D., Meehan, W., Blackburn, J. Semino, O., Scozzari, R., Cruciani, F., Taha, A., Shaari, N.K., Raja, J.M., Ismail, P., Zainuddin, Z., Goodwin, W., Bulbeck, D., Bandelt, H.J., Oppenheimer, S. Torroni, A., Richards, M., 2005. Single, rapid coastal settlement of Asia revealed by analysis of complete mitochondrial genomes. Science 308, 1034-1036.

Macchiarelli, R., 2009. From Africa to Asia through Arabia: models, predictions, an witnesses of first phases of human settlement. In: Suleimenov, O., Iwamoto, W. (Eds.), First Great Migrations of Peoples. UNESCO, Paris, pp. 19-25.

McBurney, C.B.M., 1967. The Haua Fteah (Cyrenaica) and the Stone Age in the South-east Mediterranean. Cambridge University Press, London.

McBrearty, S., 2003. Patterns of technological change at the origin of Homo sapiens. Before Farming 3, 1-6.

McBrearty, S., Brooks, A., 2000. The revolution that wasn't: a new interpretation of the origin of modern human behavior. Journal of Human Evolution 39, $453-563$.

McClure, H.A., 1971. The Arabian Peninsula and Prehistoric Populations. Field Research Projects, Coconut Grove, Miami.

Meignen, L., 2000. Early middle Palaeolithic blade technology in southwestern Asia. Acta Anthropologica Sinica, Bejing, 158-168.

Meignen, L., Bar Yosef, O., 1992. Middle Palaeolithic lithic variability in Kebara cave, Mount Carmel, Israel. In: Akazawa, T., Aoki, K., Kimura, T. (Eds.), The Evolution and Dispersal of Modern Humans in Asia. Hokusensha, Tokyo, pp. 129-148.

Mellars, P., 2006. Why did modern human populations disperse from Africa $\mathrm{ca}$ 60,000 years ago? A new model. Proceedings of the National Academy of Sciences of the United States of America 103, 9381-9386.

Miall, A.D., 1996. The Geology of Fluvial Deposits: Sedimentary Facies, Basin Analysis and Petroleum Geology. Springer-Verlag Inc., Berlin.

Middleton, M.J., Goudie, A.S., 2001. Saharan dust: sources and trajectories. Transactions of the Institute of British Geographers NS 26, 165-181.

Monigal, K., 2001. Lower and Middle Paleolithic blade industries and the dawn of the Upper Paleolithic on the Levant. Archaeology, Ethnology and Anthropology of Eurasia 1,11-24.

Moyer, C., 2003. The Organization of Lithic Technology in the Middle and Early Upper Palaeolithic Industries at the Haua Fteah. Cambridge University, Libya.

Munday, F.C., 1977. Nahal Aqev (D35): a stratified, open-air Mousterian occupation in the Avdat/Aqev area. The Avdat/Aqev Area. In: Marks, A.E. (Ed.), Prehistory and Paleoenvironments in the Central Negev, Israel, vol. II. SMU Press, Dallas, pp. 35-60.

Ohnuma, K., Akazawa, T., 1988. Reexamination of the lithic artifacts from Layer B (square 8-19) of the Amud Cave, Israel. Paléorient 14, 137-144.

Parton, A., Farrant, A.R., Leng, M.J., Schwenninger, J.L., Rose, J.I., Uerpmann, H.P. Parker, A.G., 2013. An early MIS 3 pluvial phase in southeast Arabia: climatic and archaeological implications. Quaternary International 300, 62-74.

Petraglia, M.D., Rose, J., 2009. The Evolution of Human Populations in Arabia Paleoenvironments, Prehistory and Genetics. Springer, London.

Petraglia, M.D., 2003. The lower Paleolithic of the Arabian peninsula: occupation, adaptation and dispersal. Journal of World Prehistory, 141-179.

Petraglia, M.D., 2011. Trailblazers across Arabia. Nature 470, 50-51.

Petraglia, M.D., Alsharekh, A., 2003. The Middle Paleolithic of Arabia: implications for modern human origins, behavior and dispersals. Antiquity 77, 671-684.

Petraglia, M.D., Alsharekh, A., Crassard, R., Drake, N., Groucutt, H., Parker, A.G. Roberts, R., 2011. Middle Paleolithic occupation on a last interglacial lakeshore in the Nefud Desert, Saudi Arabia. Quaternary Science Reviews 30, 1555-1559.

Petraglia, M.D., Alsharekh, A., Breeze, P., Clarkson, C., Crassard, R., Drake, N.A. Groucutt, H.S., Jennings, R., Parker, A.G., Parton, A., Roberts, R.G., Shipton, C. Matheson, C., al-Omari, A., Veall, M.A., 2012. Hominin dispersal into the Nefud desert and middle Palaeolithic settlement along the Jubbah palaeolake northern Arabia. PLoS ONE 7m, e49840.
Pleurdeau, D., 2005. Human technical behavior in the African middle stone age: the lithic assemblage of Porc-Epic cave (Dire Dawa, Ethiopia). African Archaeological Review 22, 177-197.

Preusser, F., 2009. Chronology of the impact of Quaternary climate change on continental environments in the Arabian Peninsula. Comptes Rendus Geoscience, 8-9.

Quintana-Murci, L., Semino, O., Bandelt, H.J., Passarino, K., Celreavey, M., Santachiara-Benerecetti, S., 1999. Genetic evidence of an early exit of Homo sapiens sapiens from Africa through eastern Africa. Nature Genetics 23, 437-441.

Reading, R.P., Mix, H.M., Lhagvarusen, B., Feh, C., Kane, D.P., Dulamtseren, S., Enkhbold, S., 2001. Status and distribution of khulan (Equus hemionus) in Mongolia. Journal of Zoology, 381-389.

Reineck, H.E., Singh, I.B., 1980. Depositional Sedimentary Environments. SpringerVerlag, Berlin.

Rose, J., 2007a. The Arabian corridor migration model: archaeological evidence for hominin dispersals into Oman during the middle and upper Pleistocene. Proceedings of the Seminar for Arabian Studies 37, 1-19.

Rose, J., 2007b. The Role of the Saharo-Arabian Arid Belt in the Modern Human Expansion. In: From the Mediterranean Basin to the Portuguese Atlantic Shore; Papers in Honor of Anthony Marks - Actas do IV Congresso de Arqueologia Peninsular. Universidade Do Algarve, Algarve, pp. 57-67.

Rose, J., 2010. New light on human prehistory in the Arabo-Persian Gulf Oasis. Current Anthropology 51, 849-883.

Rose, J., Petraglia, M., 2009. Tracking the origin and evolution of human populations in Arabia. In: Petraglia, M., Rose, J. (Eds.), The Evolution of Human Populations in Arabia. Paleoenvironments, Prehistory and Genetics. Springer, London, pp. 1-12.

Rose, J., Usik, V.I., Marks, A., Hilbert, Y., Galletti, C., Parton, A., Geiling, J.M., Černý, V., Morley, M., Roberts, R., 2011. The Nubian complex of Dhofar, Oman: an African middle stone age industry in southern Arabia. PLoS ONE 6, e28239.

Rosenberg, T.M., Preusser, F., Blechschmidt, I., Schwalb, A., Penkman, K., Schmid, T.W., Al-Shanti, M.A., Kadi, K., Matter, A., 2011. Humid periods in southern Arabia: windows of opportunity for modern human dispersal. Geology $39,1115-1118$.

Rosenberg, T.M., Preusser, F., Blechschmidt, I., Fleitmann, D., Jagher, R., Matter, A., 2012. Late Pleistocene palaeolake in the interior of Oman: a potential key area for the dispersal of anatomically modern humans out-of-Africa? Journal of Quaternary Science 27, 13-16.

Scholte, P., 1992. The birds of Wadi Rima, a permanently flowing mountain wadi in western Yemen. Sandgrouse 14, 93-108.

Scott-Jackson, J., Scott-Jackson, W., Rose, J., Jasim, S.A., 2008. Investigating upper Pleistocene stone tools from Sharjah, UAE: interim report. Proceedings of the Seminar for Arabian Studies 38, 43-54.

Sitzia, L., Bertran, P., Boulogne, S., Brenet, M., Crassard, R., Delagnes, A., Frouin, M. Hatté, C., Jaubert, J., Khalidi, L., Messager, E., Mercier, N., Meunier, A., Peigné, S. Queffelec, A., Tribolo, C., Macchiarelli, R., 2012. The paleoenvironment and lithic taphonomy of Shi'bat Dihya 1 middle Paleolithic site, Wadi Surdud, Yemen. Geoarchaeology: an International Journal 27, 471-491.

Stringer, C., 2000. Coasting out of Africa. Nature 405, 24-27.

Stringer, C.B., Andrews, P., 1988. Genetic and fossil evidence for the origin of modern humans. Science 239, 1263-1268.

Usik, V.I., Rose, J.I., Hilbert, Y.H., Van Peer, P., Marks, A.E., 2013. Nubian complex reduction strategies in Dhofar, southern Oman. Quaternary International 300, 244-266.

Valladas, H., Mercier, N., Joron, J.L., Reyss, J.L., 1998. GIF Laboratory dates for Middle Paleolithic Levant. In: Akazawa, T., Aoki, K., Bar-Yosef, O. (Eds.), Neanderthals and Modern Humans in Western Asia. Plenum Press, New-York, pp. 69-75.

Van Beek, G.W., Cole, G.H., JammeAluf, G.H., 1963. An Archaeological Reconnaissance in Hadramaut: a Preliminary Report, Smithsonian Institution Annual Report, Washington DC, pp. 521-545.

Van Peer, P., 1992. The Levallois Reduction Strategy. In: Monographs in World Archaeology, vol. 13. Prehistory Press, Madison.

Whalen, N.M., Pease, D.W., 1991. Archaeological survey in southwest Yemen, 1990. Paléorient 17, 127-131.

Yellen, J., Brooks, A., Helgren, D., Tappen, M., Ambrose, S., Bonnefille, R., Feathers, J., Goodfriend, G., Ludwig, K., Renne, P., Stewart, K., 2005. The archaeology of the Aduma middle stone age sites in the Awash valley, Ethiopia. PaleoAnthropology $10,25-100$. 